\title{
The Driving Force of China's Enterprise Management Innovation under the Supply-side Reform
}

\author{
Wu Jin \\ Nanfang College Of Sun Yat-sen University, Guangdong, Guangzhou, 510970
}

Keywords: supply side; enterprise management; innovation

\begin{abstract}
Faced with global economic uncertainty, weak recovery, and the impact of rising commodity prices, especially the current Sino-US trade war, many companies are faced with the situation of having to change the status quo, especially those lacking core competitiveness. The 19th National Congress of the Communist Party pointed out that China's economic development has entered a stage of high-quality development, and socialism with Chinese characteristics has entered a new era. The main contradiction in our society has been transformed into a contradiction between the growing needs of the people's better life and the development of inadequate imbalances. At present, how to carry out enterprise management innovation in the new era has attracted widespread attention from scholars at home and abroad.
\end{abstract}

Since the reform and opening up, China's economic strength has been greatly improved. Advanced management experience and technology have flowed into China, which has made tremendous contributions to the development of China's enterprises. Management innovation has played an increasingly important role in the development of enterprises. At present, China's economy has entered a new normal, and the resource conditions and dynamic factors supporting China's rapid economic growth are gradually changing. The nature of the "new normal" is a structural problem, and structural reform is urgently needed. The proposal of "supply-side structural reform" will build a new driving force for the next stage of economic growth and bring new opportunities to the development of enterprises. Therefore, the traditional enterprise management model is no longer suitable for the further development of enterprises, and innovation is the only way to promote the sustainable growth of enterprises. Enterprise growth is realized by enterprise innovation.

\section{Current Status of Chinese Enterprise Management Innovation}

Faced with the weak global economic recovery, rising commodity prices and the disappearance of demographic dividends. Many companies are faced with the situation of having to innovate. At this stage, China's enterprise management innovation is mainly manifested in the following five aspects. First, the organizational structure of enterprises in Chinese enterprise management innovation has changed. From the original state-owned to the current mixed ownership form, it has grown up to be a relatively independent economic entity. Second, the content of management in management innovation has changed. It has changed the past single production management and changed the direction to market management innovation, and may will change to financial management and capital management in the future. Third, the objects and scope of management of Chinese enterprises in management innovation have changed. From physical management to value management, from closed management to open management, the company's production efficiency and market competitiveness. Fourth, at this stage, Chinese enterprises operate independently and are responsible for their own losses. From passive management innovation to active management innovation. Fifth, the innovation of enterprise management is also reflected in the innovation of corporate culture. Many companies have begun to focus on developing their own unique corporate culture. 


\section{The Necessity of Chinese Enterprise Management Innovation in New Era}

Insufficient effectiveness on the supply side leads to misalignment of supply and demand structure, and structural overproduction is gradually aggravated. To a large extent, the effectiveness of the supply side is insufficient and the supply and demand structure is misaligned. Unbalanced input structure of supply-side factors leads to extensive economic growth and faces rising costs of land, labor, and raw materials. The rise in the price of commodities has made companies bear better production costs than ever before, so companies must innovate the traditionally backward business management model. Only by combining management systems with business management innovation can companies survive in an increasingly competitive market. Therefore, in the context of supply-side reform, Chinese enterprise management innovation has practical significance. This meaning is embodied in the following four aspects: First, the main reason for the weak competitiveness of Chinese enterprises is that corporate management is relatively weak.

When faced with such a situation, it has been proved by many scholars that the innovation of enterprise management mode is particularly important, and whether scientific and advanced management can effectively improve enterprise competitiveness. Secondly, due to the incomplete structure of the market-oriented economy, Chinese enterprises are right on a disadvantage in the competition, carrying out enterprise management innovation is the best way to improve the competitiveness of a company. Then, at present, the comprehensive capabilities of Chinese enterprises are not in conformity with the requirements of the market-oriented economy. Only by continuous management innovation, can enterprises be able to survive in the fierce competition. Finally, the rapid development of information technology has brought some pressure to the management innovation, but also promoted the innovation of management methods.

\section{The Driving Force of Chinese Enterprise Management Innovation in New Era.}

In general, driving factors of business management innovation are often limited to entrepreneurs, policies, strategies, and management issues. However, in the new era, the government advocates supply-side reforms and focuses on the optimization of the power structure, therefore, it considers the characteristics of enterprise development and corporate strategy. In view of this, the driving factors of Chinese enterprise management innovation at this stage are mainly reflected in six aspects. First, entrepreneurs. Entrepreneur is an important part of the enterprise and the most important factor in the driving force of enterprise management innovation. A good entrepreneur can often upgrade management using his excellent conditions. There are many examples in history, such as American car king Ford, Apple's CEO Jobs, Inamori Kazuo of Kyoto Ceramics Co., Ltd., Ma Yun of China's Alibaba and so on. The success of an enterprise requires entrepreneurs not only to upgrade management but also to inspire employees to innovate. Second, the development characteristics of the enterprise. Business growth is a long process in which each stage reflects different characteristics of enterprise's development. In the growth period, the survival of enterprises is an essential issue, and only by persisting in innovation can they survive. When the enterprise enters a mature development period, the innovation motivation dies down. Under the stimulation of the original inherent profits, the administrative staff will reduce the investment in innovation. If the enterprise does not pay much attention to innovation, it is likely to enter a decline phase. Therefore, innovation is the only solution to maintain the long-term nature of the enterprise life cycle. If a company really enters declining period, it has to find ways to innovate in order to enter the next new vigorous cycle. Therefore, every stage of enterprise development puts forward new requirements for enterprise management innovation. Third, corporate strategy. In general, there are two types of corporate strategy. The first is to establish on the basis of repositioning strategic innovation, and the second is to explore the management innovation model under the guidance of existing strategy. Enterprise strategy is the key to enterprise development, and innovative "top-level design" is an effective way to improve market competitiveness. Fourth, the system. The new institutional economics emphasise that the system is one of the important factors of economic growth, and the same policy system is also the main influencing factor of enterprise management 
innovation. The state has adopted macro-controls on the development and transformation of enterprises through the introduction of relevant policies. The driving role of the police is mainly reflected in the following two aspects: the enterprise can innovate as the policy is continuously adjusted. Fifth, management issues. Sometimes the problem is no longer a bad thing, and failure is the mother of success. Under the background of supply-side reform, enterprises should shift from the old and extensive management methods to the refined management methods.

\section{Measures to Improve Driving Force of Chinese Enterprises' Management Innovation in New Era}

A series of new developments in China's economy are inevitable. High-quality development is the great logic of China's economic progress. In order to make China's enterprise management innovation driven play its greater role, we should follow this "logic" and find reasons, find ways, and find strategies from the supply side in the new era. Therefore, the author suggests: First of all, improve the sense of innovation of employees. Workers are the cells of enterprise organization. They are separated from workers, and enterprises are difficult to survive. Therefore, the level of innovation of workers directly determines the innovation behavior of enterprises. The innovation of management methods is not only an entrepreneurial thing, but should establish a good development platform for all workers. Second, formulate strategic goals for corporate development. In view of the different stages of the enterprise, the corresponding strategic objectives are appropriately formulated according to the local conditions, and further innovation is carried out according to its own progress under the original management system. In addition, improve the internal structure of the enterprise and optimize the allocation of enterprise resources. Optimization of resource allocation enables resources to be fully utilized without waste and inefficiency. Finally, the country should formulate policies and systems which suitable for enterprise development, arrange and manage resources reasonably, and supervise some enterprises to carry out management innovation, combine rewards and punishments, and formulate policies and systems suitable for enterprise development to stimulate enterprise innovation. Enterprises should innovate in management methods, transform into refined management methods, and continuously improve their core competitiveness.

\section{References}

[1] Chen Xiquan. An analysis of the driving force of Chinese enterprise management innovation [J] Statistics and Management. 2017(09)

[2] Zuo Xiaode, Zhang Jincai, Chen Zhenduo. The driving force of Chinese enterprise management innovation-Comparing with Western enterprises[J]. Management World. 2015(01)

[3] Xu Chen, Sun Yuanxin. Innovation Drivers, Service Innovation and Non-Financial Performance: A Test of Search Strategy and Combination Effect in China[J]. R\&D Management. 2017(02) 